\title{
The union between technical knowledge and activism as a tool to save the donkey
}

\section{A união entre o conhecimento técnico e o ativismo de proteção animal como ferramenta para salvar os jumentos}

\author{
Gislane Junqueira Brandão ${ }^{1}$; ; Joice Heloisa de Medeiros ${ }^{2}$; Geuza Leitão Barros ${ }^{3}$; \\ Adriana Wanderley Pinho Pessoa ${ }^{4}$; Adroaldo José Zanella ${ }^{5}$ (D); Chiara Albano de Araujo Oliveira ${ }^{6}$ (D); \\ Elizabeth Macgregor ${ }^{7}$; Vânia Plaza Nunes ${ }^{8}$
}

\author{
${ }^{1}$ Frente Nacional de Defesa dos Jumentos, Salvador - BA, Brazil \\ ${ }^{2}$ União Defensora dos Animais Bicho Feliz, Salvador - BA, Brazil \\ ${ }^{3}$ União Internacional Protetora dos Animais do Ceará, Fortaleza - CE, Brazil \\ ${ }^{4}$ Universidade Estadual do Ceará, Faculdade de Medicina Veterinária, Fortaleza - CE, Brazil \\ ${ }^{5}$ Universidade de São Paulo, Faculdade de Medicina Veterinária e Zootecnia, Departamento de Medicina Veterinária Preventiva e Saúde \\ Animal, São Paulo - SP, Brazil \\ ${ }^{6}$ Universidade Federal da Bahia, Escola de Medicina Veterinária e Zootecnia, Salvador - BA, Brazil \\ ${ }^{7}$ Fórum Nacional de Proteção e Defesa Animal, Rio de Janeiro - RJ, Brazil \\ ${ }^{8}$ Fórum Nacional de Proteção e Defesa Animal, Jundiaí - SP, Brazil
}

\begin{abstract}
This case report presents the importance of articulation between legal professionals with the expertise of those who work in different areas of animal science and the activists of animal cause. The report is based on the experience that took place in the interior of the State of Bahia, with a donkey herd, the target of foreign groups interested in donkey hide exploration. The animals were rescued from mistreatment and slaughter, thanks to efficient legal work, aided by several areas of the veterinary sciences, and supported politically by the movement of animal activists. The union between activism and technical knowledge in the areas of health, breeding, nutrition, animal welfare, and legal knowledge is a tool that should not be overlooked. On the contrary, it has proved effective, confirming a strong and innovative link capable of saving animals, promoting their welfare, generating technical knowledge, and new and promising proposals for intersectoral action.
\end{abstract}

Keywords: Animal welfare. Technical cooperation. Animal protection. One health.

\section{RESUMO}

Este caso relata a experiência da articulação entre profissionais da área jurídica com a expertise daqueles que atuam nas diversas áreas da ciência animal e os militantes do ativismo da causa animal. O relato de caso toma por base a experiência ocorrida no interior do estado da Bahia, no Brasil, com um rebanho de jumentos, alvo de grupos estrangeiros interessados na exploração de pele. Os animais foram salvos de maus-tratos e do abate graças ao eficiente trabalho jurídico, auxiliado por várias áreas da ciência animal e apoiado politicamente pelo movimento de ativistas da causa animal. A união entre o ativismo e o conhecimento técnico é poderosa ferramenta capaz de estabelecer relações, conexões e promover a divulgação do conhecimento na comunidade e, principalmente, salvar a vida de animais humanos e animais não humanos.

Palavras-chave: Bem-estar animal. Cooperação técnica. Proteção animal. Saúde única.

\section{Correspondence to:}

Gislane Junqueira Brandão

Frente Nacional de Defesa dos Jumentos

R. Góes Calmon, 26, Saúde

CEP: 40045-170, Salvador - BA, Brazil

e-mail: gislanebrandao@yahoo.com.br

Received: September 30, 2020

Approved: December 22, 2020
How to cite: Brandão GJ, Medeiros JH, Barros GL, Pessoa AWP, Zanella AJ, Oliveira CAA, Macgregor E, Nunes VP. The union between technical knowledge and activism as a tool to save the donkey. Braz J Vet Res Anim Sci. 2021;58(special issue):e175282. https:// doi.org/10.11606/issn.1678-4456.bjvras.2021.175282

Donkeys and mules are frequent targets of animal protection activism, particularly among those seeking to 
free them from mistreatment in cruel situations, such as excessive loading, vehicle traction, and use at recreational activities. Levai (1998, p. 15), in a brief retrospective on defenders of nature, states on the topic that, "[...] in Brazil, among all those who worked in the defense of underprivileged animals, Antonio Vieira, a Brazilian Northeastern 17thcentury missionary, who wrote an anthological treatise on the donkey entitled "The Donkey, our Brother" was recently nominated retrospectively for the Nobel Peace Prize".

The establishment of a relationship between academia, particularly veterinary medicine and animal science, and animal protection activism could help to facilitate the implementation of legal frameworks to improve animal welfare. Technical-scientific knowledge starts from the principle of analysis of real and scientific facts and must be based on observations and experiments, which serve to attest to the veracity or falsity of a given theory. Jean Jacques Rousseau used the term "rights" concerning the treatment of animals in the early part of the 18th Century, and by Jeremy Bentham in the late 18th Century (Felipe, 2006). The history of animal protection has strong roots in 19th century Europe, including the birth of the first anti-vivisectionist entity in France in the 1860s, by the wife of the father of the science of experimentation, Marie Françoise Martin, and the founding of the Royal Society for the Prevention of Cruelty to Animals in 1824 in the United Kingdom. Activism is understood as the policy or action of using vigorous campaigning to bring about political or social change. In Brazil, the first animal protection organization, the International Union for Animal Protection and Defense (UIPA) was created in 1895 and headquartered in São Paulo, SP. It was founded by members of São Paulo's high society as a way to fight and educate society against animal abuse, especially of horses in the urban environment. At that time, these horses were subjected to severe deprivation and punishment. Later, there was much criticism from many who question the existence of these animals in the urban environment of the early twentieth century (Ostos, 2017). Despite the long history of animal protection, the movement only gained strength and public manifestation of attitudes towards animal rights in the late twentieth and early twenty-first centuries.

Among the most diverse types of activism, we find that animal activists believe that non-human animals are victims of a human society that exploits, kills, enslaves, decimates them, while acting cruelly, criminally, and denying their condition as intelligent, sentient beings who feel pain, fear, and are aware of what happens to them, and that must be respected and have their right to life and dignity recognized (Broom \& Molento, 2004; Costa et al., 2013). Activism can be manifested through various actions, including those that form movements and even end up being the source of the creation of formal entities, legal entities, duly registered, guaranteeing, according to the 1988 Federal Constitution (Brasil, 1988), the participation of civil society in the democratic system of the country. In Brazil, the activists sought action from the Public Power fulfilling its constitutional role of protecting the environment, in Article 225, Paragraph 1, Item VII, of the Federal Constitution. One of the demands was that the animals would be moved to a sanctuary with good animal welfare to remain there until their natural death, or that a policy to facilitate responsible adoption would be implemented. It should be noted that, by the omission of the Public Power in carrying out educational campaigns for responsible guarding and identification of animals, many donkeys were abandoned as a result of changes in agriculture practices, with mechanization and the exchange of animal transport for the use of motorcycles.

In Ceará State, a farm has been used to house donkeys collected from State highways since 2012, as a result of the intervention of local activists, mediated by the UIPA-CE. The partnership and support with the State Department of Transit of Ceará (DETRAN-CE) proved effective, considering that the agency agreed to invest in the collection, feeding, handling, and veterinary care and well-being of the animals. The National Donkey Task Force (NDTF), with representatives from universities, government, and NGOs, in close cooperation with DETRAN-CE, promoted measures to gather epidemiological data on the abandonment of donkeys in the State of Ceará and also established measures and protocols to improve the welfare of the animals kept at the Detran Farm, which houses up to 5,000 donkeys. However, against the expectations of activists, the Federal and State Government of Bahia acted in a quite different way. Instead of following the pioneering model provided by Ceará to protect this symbol of Northeast Brazil, Bahia sent its donkeys for slaughter (The Donkey Sanctuary, 2019). In 2016, a document was published by the Agricultural Defense Agency of Bahia (ADAB), linked to the Secretariat of Agriculture, which sought to regulate inspected slaughter of equidae.

Based on information from the internet, animal activists were aware that donkey slaughtering would begin in the city of Miguel Calmon, Bahia. The procedure was aimed at several foreign markets, including the shipment of donkey hides to China, donating part of the meat to zoos, and the rest destined for the production of animal feed. In 2016, the Defense Union of Animals - Happy Animals (Happy Animals) joined with the National Forum of Animal Defense and Protection (FNPDA) to create the National Donkeys Defense Front (NDDF). The NDDF, together with other civil society organizations, and local NGOs, sent representatives 
to the Public Ministry of Miguel Calmon, who recommended the suspension of slaughter due to irregularities in the facilities and their operation, and the slaughterhouse was fined. In that same year, a public demonstration was held in front of the ADAB, in Salvador, BA, and a petition from the NGOs Happy Animals and FNPDA were handed to the Board and requesting a meeting. At the meeting, these groups requested that all donkeys collected to be taken to a sanctuary. A few months later, the same slaughterhouse chain restarted slaughtering in another city, Amargosa, BA, with the support of the Governor of Bahia, and a new phase of the strategic campaign against this practice began.

In 2017, a demonstration was held at the Governorship entrance asking for an end to the slaughtering and again the NGOs Happy Animals and FNPDA entered with representation against the slaughtering, now in Amargosa, BA. In 2018, a new denunciation of donkey maltreatment by the NGO SOS Animals of Itapetinga, BA, led the Happy Animals and FNPDA to enter with a representation that generated an investigation initiated by the Public Ministry of Bahia. Images were disseminated through photos and videos of many dead animals, rotting on a farm where slaughter awaited, scenes of mistreatment, and featuring environmental crime. Almost 300 animals died of starvation and 750 were illegally confined, without food, water, or shade. Such a denunciation had significant national repercussions.

The NDDF, which already had many members, increased its staff and brought together more animal protection entities, veterinarians, animal scientists, lawyers, activists, and others. It also had the expertise of the members of the NDTF formed by a group of veterinarians and animal scientists, researchers, and professionals from all over Brazil. A reconnaissance visit by the NDDF was also carried out in the city of Itapetinga, BA, where the donkeys were, and where more image records were made.

In Bahia, in the period from 2016 to 2019, three slaughterhouses were known to be slaughtering donkeys, and over 100,000 donkeys were slaughtered during this period (personal communication). The animals were captured on the road or bought for up to $\mathrm{R} \$ 30$ ( $\$ 5.5$ US dollars) and taken for slaughter, and then their skins were exported to Asia.

In Salvador, the National Donkey Task Force asked for support from the Regional Council of Veterinary Medicine of Bahia (CRMVBA), which made its headquarters available to hold meetings that resulted in a report by the State Commission on Ethics, Bioethics and Animal Welfare of the CRMVBA, contrary to the slaughter of donkeys. Meetings and demonstrations against the slaughter of the donkeys took place in several municipalities of several Brazilian states, promoted by the NDDF.
Based on the legislation against the mistreatment of animals, including the Federal Constitution itself, the NDDF, through the entities Happy Animals, Mobilization Network for Animal Causes (REMCA), FNPDA and Defense and SOS Animais of Itapetinga filed a Public Civil Action against the Union and the State of Bahia on November 30, 2018. The judge of the 1st Federal Court in Salvador granted a decision injunction that prohibited the slaughter of donkeys in the State of Bahia that for almost a year prohibited the slaughter of donkeys, but the decision was suspended in September 2019.

In February 2019, photos were released on social media showing a farm in Canudos, BA, where the property was used as a warehouse rented by the Chinese, and where about 1,000 donkeys were brought, of which about 200 died of starvation and various health problems. Animals were kept unattended, including without water and food. The dead animals were placed in open ditches while many others, weakened by hunger, staggered around the farm that had no pasture or alternative food sources. The Municipal Department of Agriculture, through its staff veterinarian, prepared a report where they pointed out the cruelty to which the animals were subjected. The NDDF immediately contacted the local prosecutor, informing him of the existence of the injunction which prohibited slaughter.

Through an Infraction Notice in the field, the Institute for the Environment and Water Resources applied the apprehension of the animals. The animals were found to be in extremely poor health. Eight hundred donkeys were seized, which were being kept without an environmental license, under conditions of mistreatment. As the municipal, State and Federal agencies claimed that they were unable to take care of the animals, the FNDPA was defined as the responsible organization to guard the animals (faithful depositary).

How the animals arrived at the farm in Canudos is unknown. However, some evidence points to situations where donkeys were collected and/or purchased throughout the Northeast and then transported for up to 8 days to Canudos. Trucks arrived at the farm with many animals already dead or dying. During the confinement on the farm, before the seizure, the donkeys did not receive food or veterinary care. Unfortunately, the FNDPA, as guardian, could not allow the animals to be transported or offered for adoption until they were rehabilitated and authorized by the ADAB, which quarantined the property. The seized donkeys spent 9 months on the same property, 7 months of which was under the care of the National Donkey Task Force (nutrition and veterinary care), partially sponsored by the UK NGO, The Donkey Sanctuary. The presence of veterinarians was instrumental 
in maintaining the care of the animals and monitoring and analyzing the evolution of the case.

The ADAB carried out blood collection from the animals at the time of the seizure and, in April 2019, after 60 days, presented the first results in a Technical Note of 05/27/19 (Bahia, 2019), when interdiction of the farm was decreed since the results showed 8 animals positive for glanders (a highly contagious, zoonotic disease) and 5 for equine infectious anemia, IEA (a transmissible disease of incurable vector character and high economic impact in national equideoculture). The collections were repeated according to the health monitoring protocols and in total, after six blood collections in the 7 months, 10 animals with positive results for glanders were identified and euthanized, in addition to 14 for IEA.

Periodically, the ADAB was informed of the situation and the need to release the results of the health examinations necessary for the transit of animals, under the sanitary rules in force in the country, which were only carried out after the arrest and the definition of custody by the FNPDA. Also, there was intense support and technical guidance for this cause among technicians, lawyers, and activists throughout the period. The mobilization of the NDDF generated a meeting of efforts (which continues today) to obtain the resources for the maintenance and survival of the animals. Activists, entities, and professionals joined together to raise funds to cover expenses such as hay, medicine, land lease payments, and support for voluntary specialized labor.

After the suspension of the decision that had banned slaughter in 2020, in the middle of the Covid-19 pandemic, in Bahia, the ADAB issued Ordinance No. 13/2020, Article 8 (Bahia, 2020), which negligently provides for non-mandatory tests for glanders and IEA for donkeys sent for slaughter, facilitates the collection of donkeys, and makes the process cheaper for those interested in this exploitative practice, thereby putting both the animals and the human population at risk.

The Veterinary Council of Bahia, in response to the aforementioned Ordinance, issued Technical Note 1/2020 from the State Committee on Veterinary Public Health of the CRMVBA - dated May 28, 2020, presenting a wide range of scientific evidence supporting the need for mandatory testing for glanders, and confirming the allegations of the entities that brought the legal action against the slaughter and the need for the required guardianship. Also, the Directorate of Epidemiological Surveillance of the Secretary of Health of Bahia, issued the Epidemiological Alert 01/2020 - on Epizooty by glanders confirmed in equines, which reinforced the need to test for glanders before transporting equines.

This collaboration between activism, which generated the NDDF, and the technical knowledge of veterinarians and animal scientists, through the National Donkey Task Force, has generated enormous benefits for animals. In 2018, after meetings and discussions, a report was prepared jointly by NGOs, veterinarians, and animal scientists, with the support of CRMVBA, which requested the end of the practice of slaughtering donkeys, alerted about the danger of extinction to the species and requested the suspension of slaughtering. This document was relevant to obtain the preliminary injunction that suspended slaughter for almost a year. Another point of strong relevance was the technical support so that the need to prohibit the slaughter of donkeys and mules was properly demonstrated in that Public Civil Action, having as one of the reasons that the exploratory and unconstitutional activity of slaughter of donkeys represents a serious health risk, exposing human beings to zoonosis, and a disease that is $95 \%$ lethal. This multidisciplinary partnership confirmed the real existence of glanders in the donkeys. All facts and actions offer science-based information that the present slaughter of donkeys is generating risks for the outbreak of glanders that can worsen severely, putting the lives of non-human and human animals at risk.

On a positive note, the animals seized and placed under the care of the FNDPA with support from the entire NDDF, have miraculously survived, even after so much mistreatment and exposure to disease. One hundred and sixty-eight donkeys were rehomed on a secure property near Salvador where they are now permanently monitored. The union between activism and academia in the areas of health, breeding, nutrition, animal welfare, and legal knowledge is a tool that should not be overlooked. This case study establishes that this type of partnership is effective, confirming a strong and innovative link capable of saving animals, promoting their welfare, generating technical knowledge, and new and promising proposals for intersectoral action.

\section{Conflict of Interest}

The authors declare there is no conflict of interests.

\section{Ethics Statement}

This article does not contain any studies with human participants or animals.

\section{Acknowledgements}

The authors thank Dr. Ricardo Cattani (In Memoriam), all employees of the National Front for the Defense of Donkeys, the National Forum for Animal Protection and Defense, and the Happy Animal Defender Union. 


\section{References}

Bahia. Nota Técnica de 27 de maio de 2019. ADAB mantém medidas preventivas em relação aos asininos, p. 2. [Internet]. 2019. [cited 2020 Jul 29]. Available from: http://www.adab. ba.gov.br/modules/noticias/makepdf.php?storyid=1911.

Bahia. Portaria n. 13, de 16 de mar. de 2020. Normas gerais para emissão de GTA - Guia de Transito Animal para o abate de equídeos no estado da Bahia., p. 9. [Internet]. 2020. [cited 2020 Jul 29]. Available from: https://www.normasbrasil. com.br/norma/portaria-13-2020-ba_390720.html.

Brasil. Constituição Federal. Article 225, $\$ 1^{\circ}$, inc.VI [Internet]. Diário Oficial da União; Brasília; 1988 [cited 2020 Jul 29]. Available from: www.planalto.gov.br.

Broom DM, Molento CFM. Bem-estar animal: conceito e questões relacionadas revisão. Arch Vet Sci. 2004;9(2):1-11.

Costa AN, Molento C, Pinto L, Teixeira M, Palha M, Paixão R. The Cambridge Declaration on Consciousness in Human and Non-Human Animals. CFMV Magazine. 2013;19:59.
Felipe, ST. Fundamentação ética dos direitos animais. O legado de Humphry Primatt. Revista Brasileira de Direito Animal. 2006;1(1):207-29.

Levai LF. Direito dos animais: O direito deles e o nosso direito sobre eles. Campos do Jordão: Editora Mantiqueira; 1998. p. 159.

Ostos NSC. A luta em defesa dos animais no Brasil: uma perspectiva histórica. Cienc Cult. 2017;69(2):54-7. http:// dx.doi.org/10.21800/2317-66602017000200018.

The Donkey Sanctuary. Under the skin: update on the global crisis for donkeys and the people who depend on them [Internet]. 2019 [cited 2020 Jul 29]. Available from: https:// www.thedonkeysanctuary.org.uk/sites/uk/files/2019-12/ under-the-skin-report-english-revised-2019.pdf.

Financial Support: None. 